\title{
SAGIT RAMIYEV'S DRAMATURGY IN LITERARY AND \\ CULTURAL CONTEXT DURING THE BEGINNING OF THE XXTH CENTURY
}

\author{
Liliya F. Nuriyeva ${ }^{1}$ \\ Tagir Sh. Gilazov ${ }^{2}$ \\ Flera S. Saifulina ${ }^{3}$ \\ Zinulla Zh. Mutiev ${ }^{4}$
}

\begin{abstract}
The article analyzes the work by Sagit Ramiev, who created his own poetry school in the early twentieth century. The object of scientific analysis in this work is his plays ("Live, Zubeida, and I live"; "Exemplary Madrassah"). It is known that at the beginning of the twentieth century the Tatar people were undergoing socially spiritual and cultural renewal. The active development of the national periodical press, publishing, literary criticism has a positive effect on the creative activities of writer devoters during this period. The problem of the reconstruction of the Tatar society is raised in the works of Tatar literature classics and such famous personalities as
\end{abstract} G. Iskhaki, F. Amirkhan, G. Kulakhmetov, I. Bikkulov and others.
Among the pressing problems raised in Tatar literature at the beginning of the twentieth century, the female problem occupies an important position. Writers and playwrights believe that without a positive solution of society attitude towards women and the women issue, they can't achieve the progress in Tatar society.These social and cultural conditions positively affect the formation of the ideological and aesthetic concept of S. Ramiev's works. The study subject of this article is the continuation of the traditions begun by the classics of Tatar literature in the field of topics and problems, in the system of images and literary methods, the identification of literary relationship types in the ideological content of S.

\footnotetext{
${ }^{1}$ Kazan Federal University

${ }^{2}$ Kazan Federal University, Tel.: 89600458350. Email: tgilazov@ bk.ru

${ }^{3}$ Kazan Federal University

${ }^{4}$ West Kazakhstan State University after M.Utemisov
} 
Ramiev's plays. Along with this, attention is paid to the traditions that provide a connection with the literary and historical periods of the national art of words, as well as to the identification of individual features in S. Ramiev's works. The study of the playwright's work in the context of the literary and cultural context of the early twentieth century makes the scientific novelty of this study.The methods and principles have been used in scientific searches to comment on literary phenomena and the literary process in close interconnection and development - the principle of historicism, cultural-historical, comparative-historical, and biographical principle.

Keywords: Tatar literature, culture, literary relationships, drama, Sagit Ramiev.

\section{Introduction}

The beginning of the twentieth century, to which Sagit Ramiev's creative activity (1980-1926) belongs, is characterized by the intensive development of the educational movement. As we noted in the previous work, "The beginning of the 20th century is being defined as a period of emerging Tartar scientific thought, theory of literature, serious discourse about the literary terminology and concepts, as well as the time of achievements in this area" (Gilazov et al, 2015). Many modern researchers turn to the study of the national literary process development during the period under study: in some works, the issue of this period typography was considered; in others, children's or religious literature has become the object of research (Ibragimov et al., 2016); in some other works, they raised the problem of the comparative study of Tatar literature with the literature of Turkic peoples, as well as the peoples of the Volga and Ural regions (Mingazova et al., 2018; Mingazova \& Sulteev, 2014); the influence of folklore on literature, the penetration of folklore motifs into literary texts is also often the subject of research by modern scholars (Golikova et al., 2017).

The creative activity by $\mathrm{S}$. Ramiev begins during the years of the first Russian revolution. He has high hopes for democratic transformations in society and begins to write with enthusiasm. 
He enriches Tatar poetry with new qualities, developing it within the romantic trend; during the same years his dramatic works, short stories and novels were published. Separate verses are translated into Russian language and published in Russian periodicals. Since 1910, his work has attracted the attention of modern Tatar and Russian critics and literary scholars. But, in the Soviet period, his work remained unexplored, only in 1960-1980 the literary critic S. Sadrutdinov performed the monographic study of his versatile creative activity stages (Sadretdinov, 1973). Certain aspects of the creative heritage have been studied by such literary scholars as $\mathrm{H}$. Guzman, G. Halit, H. Minnegulov. Particular attention is paid to the work by S. Ramiev at the end of the 20th and the beginning of the 21 st centuries. The versatile activity of a unique personality begins to be considered in the context of various literary and aesthetic systems, and philosophical concepts (Ganieva, 2002). It is known that the poetry and dramaturgy by S. Ramiev develops the traditions of the East in the new social and spiritual conditions. In his dramaturgy, the ideological and aesthetic concepts of prominent writers of the early twentieth century are especially pronounced. The Kazan period of his life and the relationship of the writer with famous contemporaries was studied in the monographic work of the German scientist and Turkologist M. Friedrich (Friedrich, 1998), the phenomenon of Gisyanism in Tatar poetry was studied by the German Turkologist I. Baldauf (Baldauf, 1994).

The work presents the comprehensive study of Sagit Ramiev's dramaturgy in the context of social, literary and cultural life of the Tatars of the early twentieth century, as well as from the standpoint of modern literary science achievements, which makes the novelty of the work.

\section{Methods}

S. Ramiev's dramaturgy can be comprehensively revealed only if it is studied in relation to the identification of new phenomenon causes in Tatar literature of the early twentieth century, as well as to other literary factors. In this regard, the subject of the study was commented on the basis of historicism and in the process of the Tatar literary movement development. 
The problems raised in Ramiev's work are connected with the ideas of economically and culturally developed society development, widespread among the Tatars in the early twentieth century. The study of the playwright's works from the perspective of the cultural-historical school in literary criticism made it possible to take a fresh look at the studied author's works.

As you know, S. Ramiev is a person who has left a definite mark in public life, Tatar culture, including the history of stage art formation and development. Therefore, the biographical method allowed to deepen the scientific aspect of his play analysis. The features of Ramiev's spiritual heritage are consonant with the views of classic writers. Comparative-historic, comparative-typological methods, as well as the principle of a literary work comprehensive study were used in scientific searches.

\section{Results And Discussion}

In the studied play by Sagit Ramiev, "Live, Zubeida, and I live," social, national, and women problems are covered in close connection with enlightening ideas. The image of a romantic hero, journalist Suleiman, who wanted to serve the people and moved from the village to the city, leaving his parents behind, is revealed in the center of the work. The prototype of this image is the author himself. There is much in common with the poet both in the description of appearance and in his behavior. A special place in the work is given to Zubeida's image. Many woman problems are revealed in the work through her thoughts and actions. The main element of the work is the disclosure of the idea that a woman should have the right to education and that she should fight for her fortune. This line of the work is also associated with the idea of the social foundation transformation of the Tatar society.

The author sees the reasons that women are "dolls" in the hands of men, a stereotype of a view on women as "underdeveloped" personalities, in people ignorance, that they have no desire for education. This idea is proved by Zubeida's actions. Her father, Sadyyk Bai, referring to the wealth of this kind, decides to marry his daughter to Gizzzulla's son (who is rich) - Zarif. Then, feeling his daughter's attitude towards Suleiman, the father agrees to 
marry her to an educated and wellmannered guy, although he did not have any wealth. Zuleikha tells her friend that she achieved this happiness herself, with her own efforts.

They provided the explanation of the reasons for the difficult life situation of Tatar women by their lack of education, indifference to their fate; Zubeid's easy achievement of his happiness is explained by romantic and enlightening views on the life by the author of the work.

The harmony of the play with the dramas that saw the light at the beginning of the twentieth century can be traced both in the disclosure of the system of images, as well as in the characteristic features and actions of the main characters. Certain character traits of the rich Zubeida's daughter are activity and decisiveness reminiscent of Galia from the drama by G. Iskhaki "The Marriage Agreement" (1907), and Suleiman, like Ibrahim in the work by G. Iskhaki, is not rich, but educated and well-mannered. He understands social inequality and does not dare to be the first to open up to a girl. In addition, the play also has similarities with the drama "Youth" (1909) by Fatih Amirkhan.
There are common grounds in behavior, ideals, sharply opposed to the old views by Gaziz and Suleiman. Salikhjan, justifying the reasons for the refusal to publish the newspaper, indicates that Suleiman wears long hair, does not go to prayers and recommends that he "be at least a little like a Muslim", "appear in mosques, behave like an ordinary representative of the people". And he cites the example of an ill-mannered Zarif, who often drinks, but he dresses "like a Muslim" and sometimes appears on Friday prayers. In the drama "Youth", Zia, who wants to weaken the conflict between "fathers" and "children" a little, repeats the same idea.

Gayaz Iskhaki has great influence on the formation of $S$. Ramiev's view on the preservation of the people, the nation from disappearance by education of women. During the conversation with Salih, Zubeida repeats the thought of the previous author, voiced in the story "Disappearance in Two Hundred Years" (1902-1904) about the need to educate women "the mothers of the nation", who make up half the people and are the guardians of their spirit, language, "who educate future men and women" (Iskhqi, 1998). 
The play is written in the spirit of educational realism. It manifests itself not only in the elaboration of the main characters, but also in the spirit of the whole work. Separate lines from the poet poems used in the canvas of the drama also serve this purpose. This trend can be traced both in revealing the image of Suleiman and Zubeida. The author idealizes the image of a woman, elevates her to deification: "If I were a woman and I recognized myself, where could my place in religious books be?" - Suleiman asks (Ramiev, 1980).

One of the main lines of the work is the exposure of religious ignoramuses who support the old views among the people so that they can lead an idle lifestyle, taking advantage of their ignorance and indifference to their fate. Unlike other contemporaries, S. Ramiev chooses the path of revealing the duplicity of mediocre mullahs, living only for their own gain, as they say.

Zubeida acts as the defender of her interests in the fight against Dinmuhamet, who is the bulwark of old views. Calling for women, in the conditions of national realities, to fight for liberation, he proves that women who are "dolls", "goods for sale" in the hands of their parents have the right to personal happiness. In this regard, the author does not stop at this thought. He connects the renewal of the Tatar society with women, like Zubeida, who are capable of education, intellectual development and the struggle for their happiness. Thus, S. Ramiev, in the image of Zubeida, as well as in the works of contemporaries such as G. Iskhaki, F. Amirkhan, raises the question of an active person aimed at social and humanistic activities.

In the drama "Live, Zubeida, and I Live", unlike other dramatic works, the main "guardians" of the old foundations of life are the fanatical Dinmukhammet Hazret, who is an ardent supporter of the "fathers" camp, as well as the son of the wealthy Gizzatulla - an uneducated Zarif. The conflict of the work is resolved by the victory of Suleiman, who is the symbol of renewal in society, his comrade-in-arms Akhmet and Zubeida. Continuing the idea contained in the work by G. Iskhaki "Disappearance in two hundred years", the author advocates renewal in society based on "freedom in every action", in the fight against those phenomena that impede the development of society. 
In the comedy by $\mathrm{S}$. Ramiev "Model Madrasah" (1908), the realities of the old-method madrassah are represented, which continues to exist under a new sign. The play is based on the life of the Husainia Madrasah, where the author himself was educated and also taught for some time. This comedy is positively perceived and appreciated by the literary community of that time. The reviews of F. Amirkhan's ("Exemplary Madrasah") and G. Iskhaki's (Tatar Press "Exemplary Madrassah") contemporaries emphasize the novelty and literary value of the work, in which the realities of the new method madrasah are the object of criticism. Showing the external and internal sides of the madrasah, based on new principles, the author raises the pressing problems of Tatar society.

The main conflict is formed in the first acts, the author divides the heroes into three camps: the teacher Sadiyyk is the supporter of innovations, and the old madrasah leader and his assistants are on the guard of old views, as well as the teacher Akhmet and Garay, the heroes who occupy the position of "the middle". The conflict is formed on the basis of a different attitude to the educational process, to the arrangement of shakirs' life - the students. In order to uncover the realities of a progressivelooking madrassah, S. Ramiev dwells more on the image of students' leisure activities, as well as Kazyyev's behavior after the educational process. The restriction of the individual freedom, the curbing of the desire for knowledge, the use of obscene, swearing vocabulary show spiritual poverty, the bad manners of those who should be engaged in the education and upbringing of the next generation. The image of Sadik who graduated from this madrassah is in all respects opposed to the supporters of old views. He is educated, engaged in selfeducation, teaches the Russian language. $\mathrm{He}$ is not satisfied with the state of affairs in the madrasah, he is trying hard to resist this, and at the end of the work, in protest, he sharply criticizes the foundations at the educational institution and leaves the madrassah with a group of students.

The central conflict is complemented by small contradictions between individual educators and shakyrs, who also criticize the old education system, the life of shakyrs living in madrassas. It gives a negative 
assessment of the entire system of the educational and upbringing process, which cannot meet the expectations of the younger generation. This is what prompts the shakirds to leave the school.

By comic situations, irony, S. Ramiev depicts the educational process in a "progressive" madrassah and emphasizes the need for an update.

\section{Summary}

1) In the dramaturgy of classical literature representative S. Ramiev, one can feel the special influence of the renovation process of the spiritual and cultural life of Tatar society at the beginning of the twentieth century. The birth of the national press, the formation of Tatar journalism, the creation of a network of publishing houses, the opening of the Tatar theater have a positive effect on the work of the studied author.

2) The author's dramaturgy is also influenced by the ideological and aesthetic views of realistic authors of the early twentieth century, such as G. Iskhaki, F. Amirkhan and others.

3) The internal literary connections of S. Ramiev's drama and the work of contemporaries can be traced in the ideological content of the works, as well as in the literary style. They are enhanced by intertextual connections, quotes, allusions, and reminiscences.

\section{Conclusions}

Despite the fact that Sagit Ramiev, referring to the creation of a new lyrical hero, a new poetic form, substantiates his poetic school, he will also test his literary talent in the genre of dramaturgy. Continuing the tradition of enlightenment in the depiction of female images, he often turns to female motifs.

This topic is revealed by him in the context of literary works of the previous generation of writers, as well as contemporary writers. The works by G. Iskhaki had a great influence on the formation of S. Ramiev's views.

Mutual influence, typological convergence, general motives, etc. are traced in the literary heritage of writers of the early twentieth century, such as G. Iskhaki F. Amirkhan, S. Ramiev, and others.

The theme of spiritual freedom of women in Tatar society, equality of women and men in the family, and freedom to choose a life partner are especially highlighted here. Thus, the 
problems raised by the enlightenment at the end of the nineteenth century, also remain relevant.

Education, upbringing of a woman is perceived by S. Ramiev as a guarantee of the future nation, since it is a woman who educates both future men and girls.

The problem of liberating a woman from spiritual slavery, equality in the family, women's education, freethinking, freedom of choice in the work of the studied author is considered in the context of the problems of national education, the educational system update and makes up the ideological and aesthetic concept of the playwright. Thus, the work by S. Ramiev is a definite contribution to the development of Tatar drama at the beginning of the twentieth century.

\section{Acknowledgements}

The Work is Performed According to the Russian Government Program of Competitive Growth of Kazan Federal University.

\section{References}

Baldauf, I. (1994). Prometheismusin der circumrevolutionarentatarischen Lyrik, in: Bamberger Mittelasienstudien. Hrsg.

Bert G. Fragner, Birgitt Hoffman, Berlin, 25-66.

Friedrich, M. (1998). Gabdullach Tuqaj (1886-1913). Ein hochgelobter Poet im Dienst von tatarischer Nation und sowjetischem sozialismus. Wiesbaden, $340 \mathrm{p}$.

Ganieva, R. (2002). Tatar literature: traditions, interconnections. Kazan: Kazan University Press, 272 p.

Gilazov, T. S., Karabulatova, I. S., Sayfulina, F. S., Kurakova, C. M., \& Talipova, G. M. (2015). Between the East and the West-Phenomenon of Tartar Literary Criticism in The LingvoCultural Aspect. Mediterranean Journal of Social Sciences, 6(3 S2), 508.

Golikova G., Motigullina A., \& Zamalieva L. (2017). Artistic functions of the folk concept of "Water" IN the works of russian and tatar writers of the latter half of the 20th century (Works by V. Astafiev anf G. Bashirov). Modern 
Journal of Language Teaching Methods, 7(5), 72-81.

Ibragimov, B., Yusupova, N., \& Zakirzyanov, A. (2016). Ideological myth and archetypes in tatar poetry of years 1920-50s. Journal of Language and Literature, 228.

Ishaqi, G. (1998). Works: in 15 volumes: Vol. 1: Tales and short stories (18991908). [Volume compiler, the author of notes and comments L. Gaynanova; scientific rev. by M. Khasanov, R. Islamov]. Kazan: Tatar Publishing House, 399 p. (in Tatar language).

Mingazova, L., \& Sulteev, R. (2014). Tatar and English Children's Folklore: Education in Folk Traditions. Western Folklore, 73(4), 410.

Mingazova, L.I., Yuldybaeva, G.V., \& Kayumova, G. F. (2018). The Folk EpicTulyak and Susylu, - Zayatulyak and Hyuhylu: the History of Record and the. Astra Salvensis, Supplement, 2, 673-681.

Ramiev, S. (1980). At the dawn: Poems, short stories, plays, journalism [Introductory article, bibliography, notes and comments by S. Sadretdinov].

Kazan: Tatar Publishing House, 272 p.

(in Tatar language).

Sadretdinov, S. (1973). Creativity of Sagit Ramiev. Kazan: Kazan University Press, 162 p. (in the Tatar language). 